\title{
Impact of Online Learning During the Covid-19 Pandemic on the Paket $C$ Learning Program
}

\author{
Livia Astuti \\ Universitas Insan Cendekia Mandiri, Jl. Banten No 11, Bandung, West Java, Indonesia \\ liviaastuti@gmail.com
}

\begin{abstract}
Every citizen has the right to education. One of the educational pathways in Indonesia is Non-Formal Education, such as Study Groups, courses, Learning Activity Studios, tutoring, training centres, and the like. Non-formal education students are usually called Learning Citizens, teachers for learning residents are called teaching tutors. Nonformal education has a flexible implementation, regulations, and a curriculum that focuses on one or a few lessons. Non-formal education emphasizes one or several studies to gain knowledge and skills in specific fields relatively quickly compared to formal education. The Covid-19 pandemic has not only hit Indonesia but the whole world. The order of education has changed, which was initially face-to-face, now it has to be online. Residents of learning and tutors are forced to operate online media for continuous learning. This study aims to analyze the positive and negative impacts of online or distance learning during the Covid-19 pandemic. The method used is Literature Study, data obtained by collecting library data from news, journals, magazines, theses, and books, then recorded and processed into research material. The study results show that online learning has a negative impact, namely the network is not adequate as a result, learning residents experience failure to understand. With the material presented, enthusiasm decreases; limited facilities in online learning; expensive internet quota. The positive impact of online education is that knowledge is more practical; delivery of material/information can reach large numbers; more interested in online, civil servants and learning residents gain new experiences. In general, there are more negative impacts than positive ones. So it needs further development research, focusing on the best online learning methods.
\end{abstract}

Setiap warga negara berhak mendapat pendidikan. Salah satu jalur pendidikan di Indonesia adalah Pendidikan Non Formal seperti Kelompok Belajar, tempat kursus, Sanggar Kegiatan Belajar, bimbingan belajar, balai pelatihan dan sejenisnya. Peserta didik pendidikan Nonformal biasa disebut Warga Belajar, guru bagi warga belajar disebut pamong belajar. Pendidikan non formal memiliki waktu yang fleksibel dalam pelaksanaan, tata tertib, hingga kurikulum yang cenderung fokus pada satu atau beberapa pelajaran saja. Pendidikan non formal menekankan pada satu atau beberapa pelajaran dengan tujuan agar warga belajar bisa mendapatkan ilmu dan pengetahuan, kemahiran dalam bidang tertentu dalam waktu yang relative singkat dibandingkan dengan jalur pendidikan formal. Pandemi covid-19 tidak hanya melanda Indonesia tetapi seluruh dunia, tatanan pendidikan pun 
menjadi berubah yang semula dengan tatap muka kini harus dengan daring atau online. Warga belajar dan pamong belajar dipaksa untuk bisa mengoperasikan media online demi keberlangsungan pembelajaran. Penelitian ini bertujuan untuk menganalisis dampak positif dan negatif pembelajaran daring atau jarak jauh di masa pandemi Covid-19. Metode yang digunakan adalah Studi Literatur, data diperoleh dengan pengumpulan data Pustaka dari berita, jurnal, majalah, skripsi, maupun buku yang kemudian dicatat dan diolah menjadi bahan penelitian. Hasil penelitian menunjukkan pembelajaran daring memiliki dampak negatif yaitu jaringan tidak memadai akibatnya warga belajar mengalami gagal paham.dengan materi yang disampaikan semangat menjadi turun; keterbatasan fasilitas dalam pembelajaran daring; kuota internet mahal. Dampak positif pembelajaran daring adalah pembelajaran lebih praktis; penyampaian materi/ informasi dapat menjangkau jumlah besar; lebih tertarik dengan daring, pamong dan warga belajar memperoleh pengalaman baru. Secara umum masih lebih banyak dampak negatif daripada positif. Sehingga perlu Penelitian pengembangan lebih lanjut, fokus pada metode terbaik pembelajaran online.

Keywords: Impact, Online Learning, Covid-19, Pursuing Package C.

Received: October 30, 2021; Revised: November 21, 2021; Accepted: December 15, 2021

\section{INTRODUCTION}

Teaching and learning activities are ancient relics of humans that have undergone a long evolution and gave birth to the best learning interaction methods. Along with the times, science and technology have also developed that follow and are helpful for daily human life. Human resources are the main element in every activity (Nengsih, Tahyudun, \& I. A. Hakim, 2020). To achieve quality human resources, a learning and learning process is needed. The learning process is obtained through human abilities from time to time and the role of society in the life cycle.

The community is a social group with great potential if it can direct its ability to develop various competencies that can provide added value in their lives (Prita, 2015). The problem is the role of the community, often hampered by ignorance of the issues of their own lives. Therefore, it is necessary to develop a series of educational programs that are much more comprehensive to build public awareness to be involved in a much more optimal process of community empowerment.

Education is an absolute requirement and is protected by the state, as stated in the 1945 Constitution of the Republic of Indonesia Article 31 paragraph 1, which reads that every citizen has the right to education (Zulkarnaen, 2021). From this sentence, it is clear how important education is. There are many varieties and types of education. Still, at least we know that in Indonesia, there are 3 (three) educational system paths that can be taken to continue receiving an education to survive and compete in the development of the times and the current generation. 3 (three) recognized educational system pathways are Formal Education, Informal Education, and Non-Formal Education. 
Formal education is an educational path that focuses on graduating on time and getting legal recognition, in this case, a diploma. Traditional education has several levels, from primary and secondary to higher education. Informal education is a family and community-based educational path where classmates are parents, brothers or sisters, grandparents at home. At the same time, the older siblings are the surrounding environment with a vital role in the continuity of Informal education. By its understanding, this education has the most complex scope compared to the formal and non-formal education pathways. Academics give informal education in the family sphere as family education. This family education has many sub-materials ranging from moral education, spiritual education, academic education, social education, and even sex education which should have started to be taught from the family scope. Non-Formal Education, This education is carried out outside the hours of formal education. For example, study groups, course venues, Learning Activity Studios, tutoring, training centres and the like. Non-formal education students are usually called Learning Citizens.

Non-formal education has a flexible implementation, regulations, and a curriculum that focuses on one or a few lessons. Non-formal education emphasizes one or several studies to gain knowledge and skills in specific fields relatively quickly compared to formal education. The advantage of non-formal education is that the material presented is not too much. As a result, learning citizens who learn can explore the material better. It can also be a skill that can be highlighted when entering the world of work (Syam, 2017).

As one of the supra-national development systems, national education has two subsystems of education, namely in-school education and out-of-school education (Anggraini, 2017). Usually, this education is different from traditional education, especially regarding time, material, content and media. This educational path is popularly known as Out-of-School Education. Out-of-school education (PLS) existed before formal education. In its implementation, PLS is manifested in regional, cultural, religious ceremonies, learning activities in internships, and outside of formal education. Education outside of school is carried out voluntarily and selectively according to the wishes and needs of students who want to study seriously.

Non-School Education as an educational institution that is useful in improving the community's skills, knowledge, and attitudes is oriented towards developing the potential of human resources. Education outside of school has a role as a forum for the district to help improve knowledge abilities. One of the academic units for Out of School Education that provides skills learning services for learning citizens is the Learning Activity Center (SKB) (Ikhwan, Farid, Rohmad, \& Syam, 2020). The SKB is present to bridge the needs of learning residents who are not in school and school dropouts so that they can get an education equivalent to formal schooling, get a valid and recognized diploma to provide opportunities to continue their education to a higher level, and provide skills to increase knowledge so they can compete in the world. Public. The SKB has a function to develop the potential of learning citizens by emphasizing mastery and functional skills, development of attitudes and personality to create a community that likes to know to achieve independence and prosperity.

Every day since 2020, our ears are accustomed to hearing the words virus, covid-19, vaccine, as if it is like music that is often heard in our ears (Ikhwan, Anwar, \& Mahmudah, 2021). For some people, the existence of this virus is considered a 
beneficial thing but not the least bit detrimental for most humans. One sector that has experienced a significant impact in the world of education. Face-to-face learning activities at educational institutions inevitably stop, which is then carried out through distance learning. With this learning, almost all students actively participate in the teaching and learning process because they do not feel awkward or lack confidence.

The covid-19 pandemic that hit the world, especially in Indonesia, changed the learning pattern usually carried out face-to-face to be online (Boca, 2021). The system changes confused some teaching staff and learning residents, especially in the operation of online learning media.

Government Regulation Number 21 of 2020 concerning Large-Scale Social Restrictions (PSBB) in the Context of Accelerating the Handling of Coronavirus Disease (Covid-19), which covers school learning to go online restrictions on religious activities, and restrictions on activities in places or facilities general. To provide quality distance learning, the Government, through the Ministry of Education and Culture, organizes various kinds of training for teachers, tutors, tutors on methods and learning media that support online learning. In addition, the Government encourages the use of information and communication technology both independently and facilitated by the government.

Several types of online learning portals are commonly used, such as Google Meet, Zoom, and Google Scholar. Domestic outlets developed by the government include Google for education, learning houses, and online equivalents used for equality education. Learning carried out online can benefit the institution and teach citizens, but there are still many obstacles in implementing online learning. Whereas the online learning system, referred to as online, is an alternative when studying from home (BDR) to stop the spread of Covid-19 (Widianti, Musoffa, Maulana, Widayati, \& Falah, 2021).

Learning From Home (BDR) applies to all levels of education, from Kindergarten to PT. This policy is a strategic step and an initiative from the government in dealing with the Covid-19 pandemic. Learning activities are carried out remotely, without face to face, and are not limited by space and time with various social media applications (Hadiansah et al., 2021). Technically it looks simple. Tutors and residents learn, carry out learning from home. In another sense, learning activities must be free from crowds or maintain distance. The aim is to prevent the massive transmission or spread of Covid-19, so online learning is considered the best alternative in education.

Through "Learning from Home", the house that was once a place to relax and gather with the family has become a proper place for learning (Zamzami, 2020). Learning activities are also carried out remotely (Ismunandar, Gunadi, \& Runisah, 2019). Conceptually, the development of online learning is coloured by an Information Technology-based learning model in which it is adapted to the situation, conditions, and abilities of the tutors and learning residents. The Learning Activity Center (SKB) tries to facilitate the needs needed in online learning, but this makes SKB quite tricky because of the lack of the necessary facilities and the low ability of the tutors and citizens to learn about Information Technology.

This condition is certainly not only experienced by formal educational institutions but also by non-formal educational institutions such as the Center for Teaching and Learning Activities (PKBM), which are managed by the private sector and nongovernment, and the Learning Activity Center (SKB) under the guidance of the 
Education and Culture Office in the Regency or City. Is also affected. The learning system carried out in SKB has been adapted to the conditions of the learning community because not all of them can balance the implementation of learning as in traditional schools. The learning system in SKB is divided into three, namely independent learning, face-to-face learning, and tutorial learning.

One of the learning programs organized by SKB is Kejar Paket. In non-formal education, pursuing package $\mathrm{A}$ is equivalent to elementary school informal education, so seeking package $\mathrm{B}$ is equivalent to junior high school, and following package $\mathrm{C}$ is equal to high school. In particular, this paper will focus more on implementing the package C pursuit (Muarifuddin, Prasetyo, \& Sari, 2018).

One of the equality programs in the Learning Activity Center (SKB) is Kejar Paket C, an equality education program in the non-formal education pathway. Pursuing package $\mathrm{C}$ in its development is integrated with skills education so that learning citizens can compete and survive in community life (Hidayat, 2017).

The education program for the pursuit of equality in package $\mathrm{C}$ is expected to produce graduates who have vocational skills or life skills that are not only cognitive abilities because the majority of learning residents who enter the pursuit of package $\mathrm{C}$ are those who want a learning style that is not monotonous and with the hope that after graduation they can immediately work. Therefore, learning conditions that attract attention and focus are also very effective.

The pandemic period requires learning to continue online. This learning is an educational innovation effort that utilizes information technology in its implementation online through a web network with unlimited participants using various technological media. Online learning can make students more effective and comfortable amid the Covid-19 pandemic (Herliandry, Nurhasanah, Suban, \& Kuswanto, 2020).

In fact, in online learning, parents, or other assistants, are very much needed to control the attitudes and behaviour of learning residents during education because the tutor cannot control it as a result of not meeting face-to-face (Asmuni, 2020). Submission of material online is less understandable by students. In addition, teachers have weaknesses in IT strengthening and limited access to student supervision from students in the form of inactivity, which reduces the quality of learning, limited supporting facilities and internet network access and limited time for parents or assistants in helping online education.

Based on the facts above, it is necessary to study in-depth the impact of online learning during the Covid-19 pandemic on residents learning to pursue package $\mathrm{C}$. This study aims to analyze the positive and negative effects of online learning.

\section{METHOD}

The research method used is Literature Study, a series of activities related to collecting library data, reading and taking notes, and managing research materials in which data and information collection are obtained from various materials such as journals, news, theses, and other documents. This study uses secondary data from news, journals, and articles as the basis for writing in this study. Literature study, also known as literature study, is defined as a process related to library data collection methods, then the 
records are processed into research material. The main characteristic of the Literature Study is to take data from previous studies that are already valid. The literature study is related to collecting literacy data processed into research material (Ikhwan, 2021).

This research method was chosen because of the pandemic conditions that limited the space for researchers to attend directly to the research location due to social restrictions. Because they have been dealing with data that is already available, then library data is a secondary source, or researchers get data from second hands instead of original data directly from field research. Lastly, data from literature is not limited to space and time. After all the data has been collected, then the results of the data are poured into the descriptive form to explain what happened from the problems and the results.

\section{RESULT AND DISCUSSION}

For more than a year, the COVID-19 pandemic has become a part of our daily lives, including the world of education. The critical situation during the pandemic made face-to-face learning activities that have become part of learning replaced with online learning. However, not all private and public educational institutions are ready to implement online education.

Before the pandemic, learning activities were usually face-to-face and related to activities in the classroom and outside the school (Churiyah, Basuki, Dharma, \& Sakdiyyah, 2020). Currently, almost $70 \%$ of learning is still done online, so innovations from educators must be more creative and have a broader scope so that the learning process can run effectively and efficiently (Sugiarto, 2020). Learning media used by retaining residents can use smartphones based on Android or IOS. Learning can be made as interactive as possible through animation and other learning media such as zoom, google meet, webex, google classroom, online equivalent, etc.

The Directorate of Literacy and Equality Education Development, Ministry of Education and Culture launched the Online system, a learning management system application designed for distance learning. Not only applications provided by the government, other local and international applications can also be used by educational institutions.

Some of the applications commonly used by participants of learning catch up packages are google meet, Zoom, and online equivalent. Through this application, retaining residents are given convenience in learning. They can control the implementation of digital classes independently and make it easier for residents to pursue learning packages. It is made based on a website to be accessed anywhere, not limited by time and place (Aminatun, 2020).

Daring is an acronym for two words, namely in the network. With the understanding of a system that connects two or more devices electronically. Online coverage includes: a) as resource sharing, b) efficient multimedia communication media, c) effective resource management, d) integrated message delivery system, e) more flexible access rights, and f) information system with a high level of more excellent reliability. So that online learning is a learning activity without having to face to face, done virtually, and efficient in terms of time (Pedagogik, Sutisno, \& Nurdiyanti, 2020). 
Online realizes distance learning activities, providing opportunities for anyone to access. Online learning is considered capable of meeting the needs of implementing educational programs amid a pandemic.

\section{Changes in Tanjungsari SKB Learning Patterns in the Pandemic Period}

Before the pandemic, the Purchasing Program for Package C SKB Tanjungsari Sumedang Regency was carried out three times a week. Learning is carried out through face-to-face, independent study, and tutorials. Initially, the Kejar Package C equivalency program was formed because the identification results in the Tanjungsari area were still many SMP/MTs graduates who could not continue their education to a higher elevated level due to economic and social factors. Many high school/MA children drop out of school due to the same reason, namely the economy. In addition, there are also mainly girls who drop out of school due to culture in the village who think that school for girls is useless because they will eventually return to the kitchen to take care of their family, children, and house.

The Indonesian Child Protection Commission (KPAI), Retno Listyarti said, the pandemic is thought to have had a significant impact on the number of children dropping out of school because they were forced to work to meet the economic needs of their families and the decline in the quality of education in Indonesia (Rahma, 2021). He assessed that the policy of learning from home or Distance Learning (PJJ) continues to cause problems, while the government has not found an effective solution. One of the causes rests on the Internet. Obstacles to online learning arise due to the wide digital gap between regions in Indonesia.

For the people of Tanjungsari, the weak economic factor has triggered the number of school dropouts among school-age children, especially SMA/MA. By the character of learning residents and the social conditions of the Tanjungsari community, the learning strategy of the SKB Program Through Kejar Paket C emphasizes balancing academic competence and skills.

The provision of academic material is integrated with skills. The Kejar Package C graduates gain knowledge equivalent to SMA/MA and acquire skills that can be used to work to help meet personal and family economic needs.

SKB Tanjungsari Sumedang Regency has 11 classrooms which are divided into beauty courses, sewing courses, mechanic courses, Pursuit Package A, Pursuit Package B, and Pursuit Package C, 1 Computer Laboratory room, 1 Library Room, and 2 Toilet Rooms, 1 The Head Office of the SKB, 1 Tutoring Room for Learning, 1 Hall which is quite large, all of them are in good condition and suitable for use. For the implementation of easy skills practice, in this case, it does not require tools such as machines, usually carried out in the SKB Hall. For the preparation of other skills that need assistive devices, such as sewing, beauty, mechanic courses, they are carried out directly at locations that have these facilities. In this case, the SKB cooperates with the place of practice.

Like other educational institutions, learning is usually conducive and runs effectively. This condition suddenly changed at the beginning of 2020 because Indonesia experienced conditions other countries also experienced, namely panic and precarious conditions due to the Covid-19 virus.

The government's decision to carry out online learning has been carried out since March 2020. This was decided to prevent the massive spread of the COVID-19 virus. 
This online learning is an innovation in education to balance the needs of the times in the world of education. The information that the researcher received from several resource persons, at the beginning it was decided that learning was carried out online, the senior Pamong Learning was first taught by his juniors how to use several applications that could be used to support the teaching and learning process. If they feel that they can and are running smoothly, the Learning Community will be trained to use digital platforms to support learning instead of face-to-face learning. The learning technique adapts to the conditions and policies in the SKB. The media used are Zoom meeting, google meet, google classroom, live Instagram, and whatsapp group.

The communication between the tutor and the learning community that is most often used is through WhatsApp, sms or even telephone because the SKB has not been able to facilitate learning citizens to use a digital-based learning system.

\section{Negative Impact of Online Learning Patterns}

Most residents studying at SKB Tanjungsari have dropped out of school at the high school level and already have jobs. Before the pandemic, face-to-face learning was usually held 5 (five) times a week to participate in learning according to the module. The other time was left to the learning community to continue learning independently. But during the pandemic, learning is carried out entirely online.

The government's policy for online learning is to protect the public from massive virus transmission. The implementation of face-to-face learning is replaced by online. The threat felt during a pandemic is very real. They start from the difficulty of providing online learning facilities such as a capable device, the need for a large quota, stable network conditions, and the mental readiness of learning residents who are still minimal. Although the learning quota assistance from the government has been realized, in fact, in the field, there are still many who do not get a learning quota and cannot participate in online learning because they do not have a supporting device. As a result, online learning is considered less effective because they have never used online learning media before.

The difficulties that arise then make educational institutions, tutors, and learning residents stressed with this condition. In online learning, it is impossible to guarantee that all students can take part in learning well due to several obstacles, such as the learning environment and the characteristics of each Learning Citizen. Learners often do not understand the material provided by the Learning Pamong because not all of them have an audio learning style. For those who have Visual and Audiovisual learning styles, in this case, someone who is more able to accept learning by hearing and seeing will have difficulty understanding the material.

Through online, Pamong Learn can create material uploaded to one of the learning media agreed with the Learning Community. This makes it easier for both parties, but sometimes there are unstable network problems or device problems that not all learning residents have.

Online learning can trigger boredom in education because it is too long not to interact directly. When learning, they are often reluctant to ask questions because they are tired of studying online too often. In addition, by learning online, there are more independent tasks, practical work becomes difficult even though learning in Kejar 
Paket $\mathrm{C}$ is the core of learning. Practicums conducted online have become less focused due to the limitations of materials and tools owned by the Learning Community.

Tutors of Learning have difficulties supervising the learning process due to media limitations. For example, when learning is done by teleconference, the Tutors of Learning may not necessarily be able to see the condition of the Learning Citizens because they may only be present without listening to the learning being delivered, fall asleep, or maybe because of the network that is being communicated. Insufficient to make the Learning Citizens not activate the camera.

Another negative impact of online learning is that not all Learning Citizens can operate devices and applications to support learning. The learning community seems to be forced to adapt to the online learning culture so that it requires a long adaptation so that the absorption of the material is not optimal. It was coupled with some senior tutors who do not understand technology in online learning.

In the implementation of online learning during the pandemic, several other obstacles were encountered, namely: The internet network is less stable, there are more frequent and inadequate disturbances because the location or residence of the learning residents is in rural areas, which can trigger miscommunication between the Pamong and the Learning Citizens; Learners who are usually active become passive, those who are passive become more passive, less creative, and unproductive; learning residents experience stress as a result of several things that have been previously mentioned above (Sari, 2020). Everyone certainly has different abilities in remembering, receiving, and using what they receive. This is because each person has another way of arranging everything he sees, observes, recognises or thinks about. Learners can also differ in how they receive, organize how they approach learning situations, relate their learning experiences, and respond to teaching methods.

Nadiem said that children are at risk of experiencing violence because they are trapped at home without detecting the teacher. In addition, when children no longer come to school, there is an increased risk of early marriage, exploitation of girls, and teenage pregnancy. One study found that classroom learning resulted in better academic achievement than during distance learning.

Seeing some of the adverse conditions of online learning, the researcher argues that another impact that will be felt by learning residents is the degradation of social intelligence due to not interacting with other people for too long, which can trigger a decrease in one's empathy. Another impact that learning online is the disruption of a person's mental and psychological condition due to high boredom and boredom.

Suppose we look at various efforts to minimize the negatives of distance learning, the government, educational institutions, and individuals. However, there are still many obstacles in the implementation of online learning. This raises new problems: the declining quality of understanding of learning, high saturation, and tutors who cannot monitor learning outcomes directly while learning is in progress.

\section{Positive Impact of Online Learning Patterns}

There are negative impacts. Of course, there are positive impacts. The two often coexist. The majority of resident participants studying at SKB Tanjungsari have worked with an average age of 15-40 years. The pandemic condition that changed learning patterns to online made them overwhelmed but did not dampen their enthusiasm for learning, plus government policies that required most activities to be 
stopped except for the health and food sectors. This condition makes learning residents who are average market traders motivated to learn in the hope that they have a more creative ability to attract buyers by selling their wares online.

Seeing the enthusiasm of the Tanjungsari community, online learning is still being carried out. The government, through the Learning and Sharing Teacher Movement program, allows every teacher to share ideas and practices, either through Learning Implementation Plans (RPP), articles, learning videos, and webinars so that they can provide the best learning for students even though they are still in the Covid-19 pandemic situation. 19. Learners can study the modules that have been given independently with online tutor assistance. Because the Covid-9 cases have started to decline, the face-to-face learning policy has been allowed even though it is not yet $100 \%$. Learning residents occasionally come to SKB according to what has been scheduled by the tutor.

Pursuit learning for package $\mathrm{C}$ at $\mathrm{SKB}$ is carried out in the morning and evening so that learning residents can still participate in learning after work. The curriculum design applied is a functional curriculum developed by the learning objectives of equality education, namely supporting everyday life. Learning residents are equipped with entrepreneurial skills and abilities. It is intended that graduates of the Kejar Package $\mathrm{C}$ equivalency have life and entrepreneurial skills according to their potential and regional potential (Mauliddina \& Muhayat, 2020).

Distance learning makes learning residents feel freer because learning activities can be done while doing other activities. Online learning has the flexibility of learning time, and you can study anywhere and anytime. They benefit from this with positive activities at home, especially for learning residents who have trading businesses and are already married. For most residents, online learning is an alternative method that does not require them to attend SKB. Flexible study time can be done anywhere, anytime, so it can save time. Tutors of learning can deliver materials or assignments quickly, and learning residents can access learning materials and charges easily and deliver projects quickly, not limited by time and space (Adi, Oka, \& Wati, 2021).

In addition, the online learning method forms a spirit of independent learning because the tutor only provides material through files and then requires residents to learn to find explanations for the material themselves. Residents learn faster to get material from their tutors, and teaching residents can access learning applications for 24 hours. In addition, online learning activities no longer require physical contact, which is susceptible to virus transmission. Learners can look for additional references to add insight and adapt to their respective learning styles and access various learning materials anytime and anywhere.

\section{CONCLUSION}

Overall, online learning during the pandemic period for residents learning to pursue package $\mathrm{C}$ when implemented remotely has positive and negative impacts. The adverse effects of distance learning are, among others, that the network conditions in each region are not always available and stable. As a result, they cannot follow the lesson properly. Not all learning residents have an audio learning style. As a result, they have difficulties understanding the learning materials presented by the tutors. For some learning residents who are generally traders, the need for a large quota becomes 
an obstacle because it requires a large amount of money while they also share their income to meet family needs. This further complicates the situation.

Another impact of online learning triggers the risk of Learning Loss due to high saturation and boredom. As a result, the focus on education has decreased due to the inability of the brain to receive learning material. Professor of the Islamic University of Indonesia (UII) Edy Suandi Hamid said that simply learning loss is students' loss of academic ability, knowledge, or skills. Resolving and avoiding learning loss is not easy, but that doesn't mean it can't be done.

While the positive impact of online learning is that it is more practical, residents can learn while working or doing other positive things at home. Not limited by time and place and the delivery of information between tutors and learning residents is faster and can reach more significant numbers. In addition, online learning methods can form a person's independent spirit because learning residents are required to explain the materials provided by the tutor.

Many learning residents and tutors are interested in getting new experiences related to online learning. From the results of this study, it is hoped that it can be a reference material for various parties in organizing online knowledge for non-formal and formal institutions. This research is also expected to be a study material for other researchers and further research. Moving the learning system to online really must be prepared carefully. In general, judging from the impact of online learning, it turns out that there are still more negative impacts than positive ones. So that further development research is needed and focuses on the best methods of online learning or blended learning to increase learning motivation. They are teaching citizens or students in general in online education during the covid-19 pandemic.

\section{REFERENCES}

[1] Adi, N. N. S., Oka, D. N., \& Wati, N. M. S. (2021). Dampak Positif dan Negatif Pembelajaran Jarak Jauh di Masa Pandemi COVID-19. Jurnal Ilmiah Pendidikan Dan Pembelajaran (JIPP), 43-48. https://doi.org/http://dx.doi.org/10.23887/jipp.v5i1.32803

[2] Aminatun, S. (2020). Pengaruh E-Learning Terhadap Minat Belajar Peserta Didik Padaprogram Kejar Paket C Di Pkbm Pioneerkaranganyar. UNNES.

[3] Anggraini, W. W. (2017). Efektifitas Program Pendidikan Luar Sekolah Dalam Kejar Paket C di Pusat Kegiatan Belajar Masyarakat "Variant Centre" Keluarahan Petemon Kecamatan Sawahan Kota Surabaya. APLIKASI ADMINISTRASI, 20(1), $39-51$.

[4] Asmuni, A. (2020). Problematika Pembelajaran Daring di Masa Pandemi Covid-19 dan Solusi Pemecahannya. Jurnal Paedagogy, 7(4), 281. https://doi.org/10.33394/jp.v7i4.2941

[5] Boca, G. D. (2021). Factors influencing students' behaviour and attitude towards online education during covid-19. Sustainability (Switzerland), 13(1), 3.

[6] Churiyah, M., Basuki, A., Dharma, B. A., \& Sakdiyyah, D. A. (2020). Mobile Learning Application Berbasis Android : Peran Guru Dalam Pembelajaran Peserta Didik. Jurnal Graha Pengabdian, 2(3), 283-295. 
[7] Hadiansah, D., Pringgandinie, D. R., Winarti, A., Astuti, L., Putra, F. S. D., \& Rahaju, A. (2021). Sosialisasi Pemanfataan Aplikasi Media Sosial Dalam Pembelajaran Daring Selama Pandemi Covid-19 Pada TK Al-Zharufa Kota Cimahi. Abdi Wiralodra: Jurnal Pengabdian Kepada Masyarakat, 3(1), 1-16. https://doi.org/10.31943/abdi.v3i1.33

[8] Herliandry, L. D., Nurhasanah, Suban, M. E., \& Kuswanto, H. (2020). Pembelajaran Pada Masa Pandemi Covid-19. Jurnal Teknologi Pendidikan, 22(1), 65-70. https://doi.org/https://doi.org/10.21009/jtp.v22i1.15286

[9] Hidayat, D. (2017). Pengelolaan Pembelajaran Berbasis Kewirausahaan Masyarakat Program Kejar Paket C. Journal of Nonformal Education, 3(1), 1-10. https://doi.org/https://doi.org/10.15294/jne.v3i1.8727

[10] Ikhwan, A. (2021). Metode Penelitian Dasar (Mengenal Model Penelitian dan Sistematikanya). Tulungagung: STAI Muhammadiyah Tulungagung.

[11] Ikhwan, A., Anwar, S., \& Mahmudah, N. (2021). Tahsin and Tahfidz Learning System at Integrated Islamic Elementary School (SDIT) Insan Madani During the Pandemic Covid-19. Al-Hayat: Journal of Islamic Education (AJIE), 5(1), 1-11.

[12] Ikhwan, A., Farid, M., Rohmad, A., \& Syam, A. R. (2020). Revitalization of Islamic Education Teachers in the Development of Student Personality. 1st Borobudur International Symposium on Humanities, Economics and Social Sciences (BIS-HESS 2019), 162-165.

[13] Ismunandar, D., Gunadi, F., \& Runisah, L. N. (2019). Pelatihan Penggunaan Geogebra Sebagai Upaya Untuk Meningkatkan Profesionalisme Guru Smp/Mts Di Kecamatan Sindang Indramayu. ABDI WIRALODRA, 1(2), 67-79. https://doi.org/https://doi.org/10.31943/abdi.v1i2.12

[14] Mauliddina, R., \& Muhayat, I. (2020). The Effect of Curriculum Implementation on the Performance of SDIT Albanna Denpasar Teachers. Al-Hayat: Journal of Islamic Education, 4(2), 223-234.

[15] Muarifuddin, M., Prasetyo, F. W., \& Sari, N. P. (2018). Model Desain Pembelajaran Pendidikan Kesetaraan Kejar Paket C di Satuan Pendidikan Nonformal Kota Semarang. Journal of Nonformal Education and Community $\begin{array}{lllllll}\text { Empowerment, } & 2(2), & 1 & 5 & 7-1 & 6 & 1 .\end{array}$ https://doi.org/https://doi.org/10.15294/pls.v2i2.26835

[16] Nengsih, Y. K., Tahyudun, D., \& I. A. Hakim, P. (2020). Peran Sanggar Kegiatan Belajar (SKB) Sebagai Satuan Pendidikan Luar Sekolah Dalam Membangun Mutu Sumber Daya Manusia. JURNAL COMM-EDU, 3(3).

[17] Pedagogik, J. R., Sutisno, A. N., \& Nurdiyanti, D. (2020). This work is licensed under a Creative Commons Attribution-ShareAlike 4.0 International License. DWIJA CENDEKIA: Jurnal Riset Pedagogik, 4(2), 265-273.

[18] Prita, K. (2015). Optimalisasi Peran Masyaarakat dalam Pemberdayaan Masyarakat Melalui Pendidikan Luar Sekolah. Jurnal Empowerment, 3(1), 50-57.

[19] Rahma, A. (2021). KPAI Ungkap Penyebab Turunnya Kualitas Pendidikan di Masa Pandemi. Retrieved from Tempo website: https://nasional.tempo.co/read/1458268/kpai-ungkap-penyebab-turunnya-kualitaspendidikan-di-masa-pandemi 
[20] Sari, G. A. (2020). Dampak Sistem Kegiatan Belajar Mengajar (Kbm) Daring Akibat Covid-19 Terhadap Siswa. JURNAL IKA, 8(2), 462-470.

[21] Sugiarto, A. (2020). Dampak Positif Pembelajaran Online Dalam Sistem Pendidikan Keperawatan Pasca Pandemi Covid 19. Jurnal Perawat Indonesia, 4(3), 432-436.

[22] Syam, A. R. (2017). Posisi Manajemen Kurikulum Dan Pembelajaran Dalam Pendidikan. Muaddib: Studi Kependidikan Dan Keislaman, 7(1), 33-46.

[23] Widianti, T. P., Musoffa, S., Maulana, M. I., Widayati, A. S., \& Falah, R. Z. (2021). Pembelajaran Daring Masa Pandemi Covid-19 Di Sekolah Indonesia Kuala Lumpur. Jurnal Pendidikan Islam, 18(1).

[24]Zamzami, E. M. (2020). Aplikasi Edutainment Pendukung Pembelajaran Jarak Jauh TK Merujuk Standar Nasional PAUD. Jurnal Obsesi : Jurnal Pendidikan Anak Usia Dini, 5(2), 985-995. https://doi.org/10.31004/obsesi.v5i2.750

[25]Zulkarnaen, R. P. (2021). Tiga Jalur Dalam Satu Sistem Pendidikan (Bagian Satu). Retrieved from Edulogy.id website: https://edulogy.id/tiga-jalur-dalam-satu-sistempendidikan-bagian-satu/ 